\title{
Energy wood from forests-stakeholder perceptions in five European countries
}

\author{
Dörte Marie Peters ${ }^{*}$, Kristina Wirth ${ }^{2}$, Britta Böhr ${ }^{3}$, Francesca Ferranti ${ }^{4}$, Elena Górriz-Mifsud ${ }^{5}$, Leena Kärkkäinen ${ }^{6}$, \\ Janez Krč ${ }^{7}$, Mikko Kurttila ${ }^{6}$, Vasja Leban${ }^{7}$, Berit H Lindstad ${ }^{8}$, Špela Pezdevšek Malovrh, Till Pistorius ${ }^{9}$, \\ Regina Rhodius ${ }^{1}$, Birger Solberg ${ }^{8}$ and Lidija Zadnik Stirn ${ }^{7}$
}

\begin{abstract}
Background: In the last decade, the demand for and supply of energy wood from forests has increased, and experts expect a further increase in the future due to political and societal changes. The objective of this paper was to provide a qualitative analysis of stakeholders' perceptions of current and future trade-offs as well as of synergies between energy wood production and use and other forest ecosystem services (ES).

Methods: We developed an explorative research approach and conducted semi-structured interviews with a total of 103 interviewees of six selected stakeholder groups in five European countries: Finland, Germany, Norway, Slovenia and Spain. For the analysis, we adopted a qualitative content analysis approach.

Results: The results of this empirical study indicate that, across the five countries, stakeholders perceive similar trade-offs and synergies. Stakeholders perceive a strong synergy with employment whereas trade-offs regarding conservation of biodiversity are the most critical issue related to energy wood production in forests. Furthermore, stakeholders continue the classic debate about forest protection versus forest use in the energy wood context.

Conclusions: Effects of energy wood production and use need to be taken into account in policy development and forest management in order to address current and future trade-offs and to tap the full potential of synergies related to other forest ES. Different characteristics of countries and regions need to be considered, and decisions need to be fostered by long-term and far-reaching political frameworks.
\end{abstract}

Keywords: Biodiversity conservation; Bioenergy; Employment; Forest ecosystem services; Fuelwood; Qualitative interviews; Synergies; Trade-offs; Woody biomass

\section{Background}

Forests fulfil different functions and provide a variety of ecosystem services (ES) which are categorised into provisioning services such as timber supply, regulating services such as hydrological functions, supporting services such as biodiversity, and cultural services such as recreation [1, 2]. Particular ES offer socio-cultural or economic benefits such as health, employment and income [3]. The demand for ES is dynamic and influenced by societal transformations, political preferences and changing environmental conditions $[1,4]$.

\footnotetext{
* Correspondence: doerte.peters@ifp.uni-freiburg.de

${ }^{1}$ Chair of Forest and Environmental Policy, University of Freiburg,

Tennenbacher Str. 4, Freiburg 79106, Germany

Full list of author information is available at the end of the article
}

In the last decade, the demand for energy wood in Europe increased and experts expect a further increase in future due to socio-political changes $[5,6]$. Table 1 provides an overview of national renewable energy targets for the year 2020, shares of renewable energies in the year 2005, and shares of woody biomass in the countries investigated in this study in the year 2011. Political reasons for promoting energy wood-in addition to its renewable and storable characteristics-are an increase in security and diversity of energy supply, as well as relatively low and less volatile energy prices compared to fossil energy sources [6, 7]. Another argument, but one which remains the subject of debate, is that global efforts to mitigate climate change rely on forests and their increasingly important role as suppliers of biomass for securing a carbon-neutral energy supply in the future $[6,8]$.

\section{实}

(c) 2015 Peters et al.; licensee Springer. This is an Open Access article distributed under the terms of the Creative Commons Attribution License (http://creativecommons.org/licenses/by/4.0), which permits unrestricted use, distribution, and reproduction in any medium, provided the original work is properly credited. 
Table 1 Overview of renewable energy targets and share of woody biomass in renewable energies per country

\begin{tabular}{|c|c|c|c|c|c|}
\hline & Finland & Germany & Norway & Slovenia & Spain \\
\hline Renewable energy target 2020/share in 2005, \% [50, 78] & $38 / 28.5$ & $18 / 5.8$ & $67.5 / 60.1$ & $25 / 16.2$ & $20 / 8.7$ \\
\hline Share of woody biomass in renewable energies 2011, \% [79] & 79.5 & 37.7 & 6.9 & 43.8 & - \\
\hline
\end{tabular}

These political objectives are supported by a variety of policy instruments [6]. Simultaneously, other demands on forests are also increasing: for example, the emphasis on environmental and nature conservation aims which are often linked to adaptation to climate change, or recreational use [4, 9]. Consequently, promoting the provision of one specific forest ecosystem service such as the provision of biomass for energy purposes, can have notable effects on other services and result in unexpected trade-offs $[10,11]$.

Given that fostering energy wood production may substantially affect other forest ES, there is a need to scrutinise these effects. Trade-offs can be defined as "the increase of the provisioning of one ecosystem service and the simultaneous decline of another service at the same location" [12]. Policies which do not take into account potential trade-offs, risk aggravating existing rivalries for services in specific areas and exacerbating conflicts. Concerns about soil protection, nutrient supply, water quality, carbon neutrality, biodiversity and global sustainability issues in particular are frequently discussed in literature [7, 8, 13-17]. At the same time, there is potential for synergies, which "allow for simultaneous enhancement of more than one ecosystem service" [12]. In literature, synergies include economic, ecological and social aspects, e.g. concerning biodiversity, fire prevention, profitability of forestry and timber production, employment and rural development $[7,8$, $14,15,17,18]$.

Trade-offs and synergies remain difficult to predict since they are influenced by several dynamic factors, including climate change, time and spatial scale, forest types and other specific local conditions [13, 19-22]. Debates about specific policy measures to adequately cope with the described trade-offs and synergies are ongoing $[7,8,11,14,17,21,23]$. A crucial step regarding policy design is to take into account stakeholder perspectives and preferences: Stakeholders play a role in decisionmaking and implementation processes by attributing different weight to particular aspects, depending on their interests and values. In this context, several recent studies concentrate on forest managers' diverse attitudes towards energy wood production [24-31]. With our study, we aim to give an overview of perceptions of a broad range of stakeholders in different European countries regarding energy wood production and use because we consider that the incorporation of diverse perceptions of different stakeholders in policy development and forest management is critical for a balanced production and use of energy wood from forests [9, 11, 21, 32, 33].

In this light, our objective is to provide a qualitative analysis of the perceptions of stakeholders from Finland, Germany, Norway, Slovenia and Spain on current and future trade-offs and synergies between energy wood production and use and other ES. The paper is structured as follows: we first outline the methodological approach and research design used in the study. Subsequently, we present the empirical results, which are then discussed in light of relevant findings from recent studies. Conclusions finalise the paper.

\section{Methods}

As the main objective of the paper was to analyse the perceptions of different stakeholders, we used an exploratory approach. For data collection, we followed the qualitative, problem-centred interview approach of Witzel [34] (see also [35]). In this way, we aimed at detecting the relevance of specific issues and individual perceptions of the respective interviewee [36]. We adopted a semi-structured interview guideline including open questions, which maintains the focus on the topic under research while allowing space for individual emphasis [36]. A shared English guideline enabled comparison amongst involved countries and a common understanding amongst partners involved. Also as a means of ensuring consistency in understanding, we defined energy wood as any kind of woody biomass from forests that is or can be used for energy purposes.

Interviews were conducted with 103 representatives of six stakeholder groups in five European countries: Finland, Germany, Norway, Slovenia and Spain. These countries were chosen as they have different preconditions and goals for energy wood production and use, e.g. diverging national policies, forest characteristics and current use of renewable energies [37, 38] (see also Table 1). The inclusion of diverse countries from Northern, Southern and Central Europe makes it possible to obtain a high variance in stakeholder perceptions about energy wood production and use in Europe. For the same reason, maximum variation sampling was used and interviewees with high heterogeneity were chosen. This purposive sampling method aims at maximising the diversity of perceptions with a rather small sample representing different interests. As an example, diverse societal interests in energy wood are represented in this study by tourism and nature conservation associations; 
forest owners are represented by forest owners associations, etc. Where possible, representatives with professional knowledge about energy wood or forests were chosen. Interviewees were categorised into stakeholder groups according to their organisational or institutional affiliation, as explained in Table 2 . The numbers of interviewees per stakeholder group as well as the total number of interviewees for each country vary across partner countries due to different financial resources available to the research partners and to the availability of contacted stakeholders to take part in the study. Interviews were conducted in native languages-face to face, by telephone or Skype-between November 2012 and September 2013, recorded for later analyses, and fully transcribed (and anonymised) in the respective language.

For the analysis of the retrieved interview material, we adopted a qualitative content analysis approach based on Mayring [39] and used the software MAXQDA (Verbi $\mathrm{GmbH}$ ). The first step of analysis was the coding of the interview transcripts by which single words, phrases or paragraphs of the interviews were categorised as the subject of the research question (see, e.g. [40]). We derived a set of preliminary codes from literature which was agreed upon by all research partners. Additionally, the individual partners deduced some additional codes during the coding process (open-coding), e.g. to include country-specific issues (see, e.g. [40]). The text sections assigned to each code were further analysed for each stakeholder group in each country. Stakeholders' perceptions were compiled in English summaries that included characteristic quotations. These summaries served as the basis for the following results, which are not claimed to have universal validity, but rather to provide insights that were identified consistently throughout the study. Where stakeholder groups are indicated, at least one interviewee from the respective group has argued along the lines illustrated.

Table 2 Number of interviews per stakeholder group and country

\begin{tabular}{lllllll}
\hline & Finland & Germany & Norway & Slovenia & Spain & Total \\
\hline Conservation $^{\mathrm{a}}$ & 1 & 3 & 5 & 4 & 2 & 15 \\
Economy $^{\mathrm{b}}$ & 3 & 13 & 2 & 4 & 2 & 24 \\
Policy $^{\mathrm{c}}$ & 1 & 4 & 0 & 4 & 1 & 10 \\
Practitioner $^{\mathrm{d}}$ & 5 & 12 & 2 & 7 & 3 & 29 \\
Science $^{\mathrm{e}}$ & 4 & 4 & 3 & 5 & 2 & 18 \\
Social $^{\mathrm{f}}$ & 2 & 1 & 2 & 2 & 0 & 7 \\
Total & 16 & 37 & 14 & 26 & 10 & 103
\end{tabular}

${ }^{a}$ Nature conservation associations

${ }^{b}$ Wood industries and associations, timber users, energy wood users

${ }^{c}$ Ministries (including forest administration)

${ }^{d}$ Forest owners associations, forest enterprises, foresters

escientific institutions, researchers

${ }^{\mathrm{f}}$ Tourism enterprises and associations

\section{Results}

The following results illustrate the trade-offs and synergies between energy wood production and use and provisioning, regulating and supporting and cultural ES, that stakeholders in Finland, Germany, Norway, Slovenia and Spain discussed during the interviews. Table 3 shows the attribution of particular trade-offs and synergies to different ES and summarises the results based on [41-43].

\section{Trade-offs and synergies relating to provisioning ES}

Regarding interrelations between energy wood and provisioning ES, interviewees identify roundwood production, the competition between material and energy use, cascade use, the marketability of wood, employment and rural development as being relevant.

Stakeholders from most of the investigated countries perceive trade-offs and synergies between energy wood production and roundwood production in terms of forest management practices. Trade-offs regarding this issue relate, for example, to a potential shortening of rotation periods due to energy wood production, which stakeholders perceive negatively in terms of forest management (Finland, Germany: conservation groups). Damage caused by energy wood harvesting is also seen as a problem (Finland: practitioner group). Conservation stakeholder groups highlight potential negative effects of an increasing intensity of forest management in the future which-related to energy wood-could foster changes in forest structure, e.g. due to an increased collection of harvesting residues (Germany, Norway). They particularly criticise whole-tree use and plantations (Germany). Additionally, forest management directed solely towards energy wood production is perceived as a bad alternative in comparison to high quality wood production (Finland, Germany, Norway, Slovenia). As emphasised by several Slovenian interviewees, this situation might occur where high quality wood production is not profitable, e.g. in small properties without economies of scale. These interviewees argued that profitability determines the purpose for which high quality wood is sold: "If one has a well-formed oak or similar, but instead he or she needs firewood, then firewood will be made out of that oak. This occurs because it would be economically nonprofitable to sell one single oak" (Slovenia: science group).

Synergies between energy wood production and roundwood production mentioned by stakeholders pertain, for instance, to the energy use of logging residues as a byproduct of final fellings without negative effects on wood production or to the harvesting of energy wood from young stands, which improves the growth of the remaining trees (Finland: practitioner group). Interviewees furthermore mention the higher merchantability of wood due to current and future energy wood production and use, which according to practitioners results in more intensive forest tending 
Table 3 Perceived trade-offs and synergies between energy wood production and use and other ES

\begin{tabular}{|c|c|c|c|c|c|}
\hline & Finland & Germany & Norway & Slovenia & Spain \\
\hline \multicolumn{6}{|l|}{ Trade-offs and synergies relating to provisioning ES } \\
\hline Roundwood production & $+/-$ & $+/-$ & $+/-$ & $+/-$ & $+/ 0$ \\
\hline Competition between material and energy use & $+/-$ & $+/-$ & $+/ 0$ & - & $+/-$ \\
\hline Cascade use $^{a}$ & 0 & $+/-$ & n.a. & + & + \\
\hline Marketability of wood, employment, rural development & + & + & + & + & + \\
\hline \multicolumn{6}{|l|}{ Trade-offs and synergies relating to regulating ES } \\
\hline Carbon dioxide $\left(\mathrm{CO}_{2}\right)$-fixation/greenhouse gas emissions/climate change mitigation & $+/-$ & $+/-$ & $+/-$ & $+/-$ & $+/-$ \\
\hline Soil and hydrology (water quantity and quality) & $+/-$ & $+/-$ & - & - & $+/-$ \\
\hline Fire prevention & n.a. & n.a. & n.a. & n.a. & + \\
\hline Air quality & - & - & - & - & - \\
\hline \multicolumn{6}{|l|}{ Trade-offs and synergies relating to supporting ES } \\
\hline Biodiversity and nature conservation & - & $+/-$ & - & - & $+/-$ \\
\hline \multicolumn{6}{|l|}{ Trade-offs and synergies relating to cultural ES } \\
\hline Recreation & $+/-$ & $+/-$ & $+/-$ & $+/-$ & $+/-$ \\
\hline
\end{tabular}

and better forest hygiene and health (Germany: practitioner group). Especially in a situation with unused stocks of wood (e.g. due to reduced paper and pulp production), stakeholders from practitioner and economy groups highlight that the economic viability of forest management plays an important role in ensuring forest use (Norway): "In the current situation, more resources can be harvested [...] harvest could be $50 \%$ higher than current levels" (Norway: economy group).

Another example of a synergy perceived by stakeholders is that energy wood production generally enables forest management by covering the costs of traditionally loss-making forestry activities (Spain: economy, policy, practitioner groups). In this respect, stakeholders do not only observe that using wood for energy entails "no more impacts than any other forestry work" (Spain: practitioner group) but also that planning of forestry interventions may minimise negative impacts on forest ES while increasing the positive effects (Spain: economy group). In line with this, Slovenian interviewees promote integrative forest management as practised in Slovenia, as it allows for a synergetic balance amongst different forest ES while minimising trade-offs: "The management of forests in Slovenia is a result of a long tradition and forest management planning and it does not have a negative impact on other functions" (Slovenia: conservation group).

In all investigated countries, the resource competition between material and energy wood use is also a key issue. For example, interviewees refer to the competition between material and energy use of small trees which they expect to increase (Finland: practitioner group) to a potential competition in which material and energy wood uses clash due to a "biomass bubble" (Spain: conservation group) or to an observed "fight" between energy and material wood industries which challenges the means of existence of the latter (Germany: economy group). A practitioner argues against the promotion of energy wood as an alternative to paper and pulp production on the basis of the lower prices that can be fetched for energy wood (Norway). However, in light of a possible decline in paper and pulp production, some stakeholders also perceive energy wood production as an economic opportunity to balance losses (Finland: science, practitioner groups, Norway: practitioner group, Spain: economy group). For example, a shift of smallsized wood assortments towards energy use might take place (Finland: practitioner, policy groups). In Germany, existing or future synergies between energy wood and material uses of wood that stakeholders observe are not made explicit. Another interviewee considers that energy and material uses are complementary rather than competing markets: "What cannot be sold for timber is sold for biomass" (Spain: science group).

In line with this understanding of material and energy uses of wood as complementary markets, stakeholders from all countries except Norway refer to the concept of cascade use. Interviewees either mention cascade use without evaluating it (Finland) or express a positive attitude towards it when wood is preferably used as material (Germany, Slovenia): "It is not directly a competition but a question of how to do it, in which order. The more 
wood is brought to usage, the more is afterwards there for burning" (Germany: economy group). Stakeholders support energy use of wood, "[...] but always at the end of the wood value chain [...]. That means: first we try to use it in some products and only then, if we cannot recycle it anymore, we use it for energy purposes. We should never use wood from forests directly in stoves" (Slovenia: science group). Particularly in Spain, stakeholders highlight the higher value of forest products that cascade use makes possible to achieve.

Another synergetic effect regarding provisioning ES is the increasing marketability of otherwise unprofitable wood assortments, which plays a role in all countries except Slovenia. This is evident in the views of stakeholders from practitioner groups (Finland, Germany) and economy groups (Norway, Spain) who consider that energy wood is, or could potentially become, a new source of income for forest owners. According to them, this would have positive effects, as it provides market opportunities for forest products that otherwise could and would not be mobilised. However, Finnish interviewees also point at the fact that procurement costs of energy wood in Finland are higher than the revenues, for instance due to long transportation distances, low price of energy wood and rising oil prices. Specific economic ideas expressed by stakeholders relate to the possible substitution of industrial round wood with birch (Betula pubescens Ehrh.) in certain areas for energy use. Moreover, the harvesting of bigger trees for energy wood would improve the profitability of energy wood harvesting (Finland).

Closely linked to the preceding aspect, stakeholders already perceive an increase in employment or expect this to occur in future due to increasing energy wood production in all countries. For instance, German (economy, practitioner groups), Norwegian (practitioner, science groups) and Spanish (economy, practitioner groups) interviewees refer to an already existing synergy, but they also expect this aspect to be relevant in the future. As an example, a Norwegian interviewee hints at positive effects of energy wood production in rural areas: "The forest sector is more important for national economic activity, and for export income, than most people know. And a lot of the economic activity takes place in rural areas with few alternatives" (Norway: practitioner group). In Spain, the alignment between energy wood production and employment is particularly important and, where possible, fostered: "A project in which we collaborate [...] deals with public forest management [...] in which we combine Mediterranean forest management with fire prevention, bioenergy use and rural development [understood as] employment" (Spain: practitioner group). Some Finnish (practitioner, science, social groups) and Slovenian (economy, practitioner groups) interviewees mainly refer to the future when speaking about the employment effect. For instance, interviewees perceive that increased energy wood production will employ local residents and hence maintain economic welfare in rural areas (Finland).

However, interviewees also refer to hindrances to achieving additional employment associated with energy wood. They note that energy wood mobilisation does not work well enough, meaning that there are no yearround duties available for all employees (Finland). Furthermore, stakeholders mention the lack of professional workforce (Finland) and the problem of outsourcing or export of energy wood production: "If we look at how the forests are threatened in general: they are being harvested and the wood is donated to other countries [...] how many workplaces might we have at home instead?" (Slovenia: practitioner group).

Some interviewees directly point at employment challenges that constitute a trade-off between the material and energy wood sectors. For instance, stakeholders in Germany (economy group) and Slovenia (economy, practitioner groups) prefer the political support of traditional wood industries rather than energy wood industries. They argue against political promotion of energy wood production because they predict a decline in competitiveness and a major loss of industrial branches and jobs as "the energy sector does not yield such a high added value and employment effect compared to the material use of wood" (Germany: economy group). In line with this, stakeholders prefer the promotion of other wood processing industries with higher added value to the production chain and more employment (Slovenia). By promoting wood processing industries, energy wood supply is expected to improve: "The development of the wood processing industry will lead to the processing of timber at home, there will be jobs [...] and from those industries we will have enough raw material for chips" (Slovenia: practitioner group).

\section{Trade-offs and synergies relating to regulating ES}

Interviewees identify climate, soil and water regulation, as well as wildfire prevention as relevant regulating ES that interact with energy wood production and use.

Within all studied countries, stakeholders discuss carbon dioxide (CO2)-fixation by forests, and consequently greenhouse gas emissions and climate change mitigation stemming from energy wood production and use; perceptions about synergetic and conflicting effects vary amongst stakeholders. As an example, some interviewees assume that burning wood does not cause any net emissions whereas others assume it does (Finland). In addition, stakeholders consider that energy wood harvesting from young stands increases the $\mathrm{CO}_{2}$-fixation of the remaining trees because of their enhanced growth (Finland). The same varied opinions occur in Germany and Norway; however, a 
slight tendency shows that German interviewees mostly see trade-offs with regulating ES when wood is used as an energy source (conservation, economy, policy groups). Representatives of all Norwegian groups point to potential synergies between energy wood and greenhouse gas emissions, while one representative of the science group states that "to harvest more from Norwegian forests [for bioenergy] will not provide positive effects on the carbon balance [...] in a 100-200 years perspective, there is no climate gain of increasing the harvests". A broader approach takes into account the substitution of fossil fuels by energy wood with positive effects: "There is potential for forests to play a great role, if managed for carbon. Bioenergy can replace fossil energy, and through this reduce the GHG emissions. So at least in the longer run, biomass replacing fossils will be positive" (Norway: practitioner group).

Stakeholders furthermore address trade-offs between the use of energy wood and climate change mitigation due to $\mathrm{CO}_{2}$ emissions, especially in the context of households' inefficient use of energy wood: "So, what is the consequence of tree harvesting and burning? Destroying something that converts $\mathrm{CO}_{2}$ into oxygen and at the same time polluting the air with carbon dioxide" (Slovenia: economy group). Spain is the only country where stakeholders generally consider forest biomass to have a neutral $\mathrm{CO}_{2}$ balance and where perceptions amongst groups were homogeneous. However, stakeholders from conservation and science groups express a preference for short transport chains to ensure real neutral $\mathrm{CO}_{2}$ balance.

Soil balance and nutrient supply are furthermore an issue in all countries except Slovenia, and mainly tradeoffs are discussed in this respect. Possible negative effects on soil nutrient balance mentioned in all countries are, for instance, rooted in an intensified extraction of wood (residues, crowns, stumps, whole trees) and following nutrient losses (Germany: all groups except social, economy; Norway: conservation, practitioner, science groups). Stakeholders generally perceive stump lifting to be in conflict with many environmental concerns (Norway). Although many Finnish stakeholders emphasise the negative effects of energy wood harvesting on soil nutrient balance, they perceive that the effects remain small because energy wood harvesting from nutrient-poor sites is not taking place. In Spain, concerns regarding soil compaction exist and some stakeholders consider that erosion of the ground layer might occur. Possible synergetic effects that interviewees express pertain to soil erosion control (Germany: economy group) and wood ash recycling (Germany: economy, science groups).

Stakeholders from different countries also highlight hydrological issues. They discuss both positive and negative impacts of energy wood production on water systems (Finland: practitioner group). Potential positive effects of thinning activities for energy wood relate to soil filtration properties and therewith to improved water quality (Spain: economy group). Stakeholders expect energy wood harvesting to have negative effects on water availability, especially in the case of bioenergy plantations (Spain). Generally, stakeholders see the consideration of hydrological issues as extremely important, e.g. in terms of drinking water supply (Slovenia: economy group).

Fire prevention is only an issue for Spanish interviewees, where a clear consensus exists amongst the stakeholders regarding the synergy between forest biomass harvesting and fire prevention.

Single stakeholders address a possible shift towards lower stability and vulnerability of forests to extreme weather events, because they perceive actual forest management to be far from optimal in terms of cuttings undertaken according to forest management plans (Slovenia: science group). Additionally, there are concerns about negative effects of increased energy wood production on forest stability (Slovenia: science group).

In all countries, stakeholders refer to air quality and risk of increased small particle emissions from oldfashioned wood stoves in private households.

\section{Trade-offs and synergies relating to supporting ES}

Interviewees in all countries and within most groups address trade-offs and synergies relating to supporting ES. They identify biodiversity and nature conservation issues, which are closely linked to political regulations.

Some stakeholders consider current legislation, certification and concepts (e.g. sustainable forest management) relating to forest management as means of addressing trade-offs with biodiversity (Germany, Slovenia, Spain): "The production of wood for energy is closely linked with the principles of sustainable forest management practices that tend to preserve natural ecosystems" (Slovenia: practitioner group). Other stakeholders perceive political regulations for biodiversity protection as being too restrictive (Spain: science group) or as diminishing energy wood production potential, e.g. in forest reserves or Natura 2000 areas (Finland, Germany: practitioner, economy groups, Slovenia). "Forestry in Catalonia is highly regulated and takes into account all these environmental issues [...] if we utilise we have to integrate many factors of protection, biodiversity, etc. - thus, at the end you can practically do nothing" (Spain: science group). These stakeholders see no additional need for regulations as long as existing frameworks regarding sustainability and nature conservation are maintained (Germany: practitioner group), and moreover they oppose land abandonment (Germany: practitioner, economy, science groups; Slovenia: economy group): "All forests should be managed, also those which play an important role for nature conservation" (Slovenia: economy 
group). Maintaining or enlarging areas of forest reserves could-from this point of view-lead to increasing import of energy wood, which might cause trade-offs with biodiversity in supplying countries (Germany: practitioner group).

In contrast, other stakeholders seek additional regulation or definition of standards regarding the impacts of energy wood harvesting on biodiversity (Finland, Germany, Spain) in order to prevent trade-offs. These interviewees perceive that increasing energy wood production leads to an intensification of forest management (e.g. harvesting of small trees or reduction of rotation period) and thus poses trade-offs with biodiversity (Germany: conservation group). Furthermore, they consider that the introduction of non-native tree species does not correlate with nature conservation aims, especially regarding the maintenance of open stands (Germany: policy group). These stakeholders accordingly demand restrictions on energy wood production, such as the definition of sustainability standards (e.g. for solid biomass use on EU level), covering e.g. protection of old and decaying trees or habitat structures, harvesting prohibitions in the breeding season, and exclusion of wood harvesting in primary forests or in forests with high biodiversity value (Germany: conservation, policy groups). Stakeholders generally express the view that negative effects on biodiversity might occur (Norway), if, e.g., harvest levels increase (Norway: science group). Furthermore, stakeholders highlight the need for further research about the importance of different assortments (such as stumps and logging residues) for biodiversity on as yet unused forest areas as well as about appropriate harvesting intensities (Finland, Norway, Spain).

Within all countries, stakeholders address the use of harvesting residues, dead wood and old-growth trees. Some stakeholders are opposed to harvesting nutrientrich residues due to the negative effects of this on some species (Germany: conservation group, Slovenia). They also highlight trade-offs between an increasing energy wood production and the protection of dead wood and old-growth trees which serve as important elements of habitat structures (Germany, Spain: conservation group). Since stumps are important for coarse wood debris and related species, stakeholders hold negative attitudes towards stump harvesting (Norway: conservation, science groups). Furthermore, stakeholders claim to leave some deadwood and respectively understory in the forest: "Not all the deadwood should be eliminated. [...] understory should be maintained according to fauna requirements" (Spain: conservation group).

In contrast, it is argued that the importance of crowns and small-sized wood for habitat structures has not been proven through sound scientific evidence (Germany: science group), and the application of old and dead wood maintenance strategies is not expected to bring tradeoffs (Germany: policy, science groups). A Finnish practitioner furthermore points out the importance of large trees for biodiversity, which in any case do not exist in commercial forests and which will thus not be threatened by energy wood production.

Stakeholders address not only trade-offs, but also synergies of energy wood production with biodiversity. For instance, they refer to residues from nature conservation measures, which are available for energy (Germany). Likewise, some stakeholders consider that the removal of energy wood from naturally poor sites is consistent with the maintenance or restoration of their habitat quality (e.g. juniper heathland). Moreover, stakeholders mention the aim to promote historical forest management such as coppice or coppice with standards for energy wood if native tree species are used (Germany). Spanish stakeholders in particular even perceive forest use in general as a tool for biodiversity conservation, as long as this is managed sustainably: "What we have attempted to prove is that with forest management, biodiversity increases and of course the Natura2000 network is protected. This isn't the case in Sweden or Germany, but here we have wildfires" (Spain: practitioner group). They refer to extended areas where thinnings for bioenergy would simultaneously have positive effects on biodiversity: "Very often [...] biomass extraction implies a chance to strengthen biodiversity [...] and avoid the abandonment of millions of hectares which are nowadays without use" (conservation group).

\section{Trade-offs and synergies relating to cultural ES}

Although cultural ES comprise much more than just recreation, this was the only issue that was raised by interviewees in this study. Recreation is an important aspect in all investigated countries in terms of trade-offs and synergies with cultural ES. However, stakeholders' opinions differ regarding effects of energy wood production on recreational forest ES. In general, many stakeholders point out that most non-professionals do not distinguish between traditional forest management and energy wood production in terms of perceived forest stand structure and appearance. Thematically, stakeholders focus on access to forests, on aesthetic values of forests, and on the collection of firewood as a recreational activity itself.

In this context, stakeholders emphasise the importance of free access to forests (Slovenia) and perceive synergies between energy wood production and recreation. This is because the production of energy wood makes it is easier to walk in the forest to, e.g. pick berries and mushrooms (Finland), or because energy wood harvesting generally improves access to the forest (Norway, Spain). With respect to aesthetic values, stakeholders argue that energy wood harvesting has a positive effect because 
people like "tidy" forests for recreation (Germany; Spain) or that landscapes are more attractive when energy wood is harvested (Finland). Another example of a synergy perceived by stakeholders is the collection of firewood as a recreational activity (Finland, Germany): "There are fire wood collectors in many areas who consider this as a sporting activity; who literally enjoy processing their own wood. Oftentimes [these belong to] very intellectual social strata, graduates who see this as a sporting challenge for their Saturday afternoon ... and [who] possibly do not reflect on the economic [aspect]" (Germany: economy group). According to a stakeholder from the Finnish social group "it is healthy to be there in the forest, oh dear, it is healthy to bustle. Both mentally and physically".

In contrast to these synergetic effects, some stakeholders also see trade-offs between energy wood production and recreation in terms of access to forests and aesthetic values. As an example, some stakeholders consider that deep skidding tracks and damage to the ground layer caused by stump harvesting, as well as damage to remaining trees caused by other energy wood harvesting complicates walking in the forest and has a negative effect on aesthetic values (Finland). In addition, some interviewees more generally perceive negative reactions from recreationists in the short-term directly after harvesting activities (Spain). In line with this, a stakeholder argues that "it is seen as a disturbance factor when large, long-lasting harvests are made, where maybe former beautiful forest paths, that people were used to, are changed into broad motorways by harvesters" (Germany: social group). Another trade-off perceived by stakeholders is stump harvesting, which could negatively affect recreational values (Norway).

\section{Discussion}

It is important to discuss the limitations of the present study, in particular, its qualitative character and limited sample size. When using a limited sample size, the influence of the choice of particular representatives (e.g. ministries) on the results is not negligible, especially as some stakeholder groups include only a few persons. Nevertheless, the objective of the study was not to be comprehensive, but to provide a qualitative overview of multiple stakeholder perceptions about energy wood production and use without claiming to be generalisable. Another limitation of the study is that qualitative studies always leave room for interpretation. This study addresses this limitation by using many unmodified quotations which make the interpretation process transparent for the reader. In terms of further research on the issue, hypotheses could be generated from the results of this study and be tested in a representative study.
Looking at differences between countries, Spain as a Southern European, Mediterranean country stands out with different aspects discussed and more synergies perceived by stakeholders, whereas aspects discussed across all other-Central and Northern European-countries are more similar and include a higher proportion of trade-offs. The risk of wildfires, which characterises Mediterranean forests [44], explains the rather positive attitude of Spanish stakeholders towards energy wood production and use. The results show that any form of profitable forest use-including energy wood production-is welcomed by Spanish stakeholders, as it makes proper forest management economically viable thus contributing to the prevention of wildfires. Aside from the Spanish case, more diversity in perceptions of trade-offs and synergies between energy wood production and use and other forest ES amongst the studied countries might have been expected. The countries investigated feature different national preconditions, especially regarding forest coverage, management, use traditions, policies and population density [25, 37, 45-48]. For instance, Finland has a long history of policies targeting bioenergy production and use, and-in contrast to the other countries-its National Renewable Energy Action Plan points to forest-based bioenergy as the main provider of renewable energy [49]. However, the targets regarding energy wood production and use within national policies and strategies each follow the EU 2020 goals on climate and renewable energy [50].

Concerning the different stakeholders, the heterogeneity of their perceptions of trade-offs and synergies related to the production and use of energy wood within and amongst groups is on the one hand surprising, e.g. regarding climate change issues or recreation. However, this heterogeneity is also identified by Hickey and Innes [51], who found forest-related stakeholder groups to differ in their perceptions within and between groups. Additionally, forest stakeholders' perceptions are especially influenced by their underlying values and strong emotional bonds [26, 51-54]. As Buijs and Lawrence [52] pointed out the handling of information by stakeholders is highly influenced by their emotions. In our study, the open interview method and the fact that stakeholders knew we would anonymise their interviews, allowed for an intimate interview situation.

On the other hand, differences across stakeholder groups appear, especially when it comes to issues which are politically charged, such as the classic debate between interests of nature conservation and forestry stakeholders. On the basis of this predominant example in our study, our research makes clear that perceptions of stakeholders from conservation groups (especially apparent in Germany, but also in other countries) differ from those of stakeholders from practitioner and economy groups, e.g. 
regarding land-freeze for conservation measures or harvesting restrictions in general. This is supported by Winkel [55] who identifies that conservation groups (in Germany) see a political need for action in order to secure the ecological dimension of sustainability in light of the shortcomings of existing forestry activities, whereas forestry groups perceive (ecological) forest sustainability as already being given and mostly see dangers related to the economic dimension of sustainability. In our study, the economic considerations follow two directions: stakeholders of economy and practitioner groups value energy wood due to the higher marketability of wood and emerging employment opportunities. However, they also see economic threats (and opportunities) related to the competition between material and energy wood uses, and some direct impacts based on the competition for wood as well as restrictions for conservation measures. Differences amongst stakeholder groups are furthermore not restricted to diverging opinions but are also apparent in relation to the specific issues on which they mainly focus.

Regarding the political framework, our findings indicate that stakeholders across countries do not expect policies targeting increased energy wood production to result in major silvicultural changes. Rather, stakeholders perceive energy wood as a by-product of regular forest management and highlight the importance of competing or rather complementary material uses. As explained above, forestry stakeholders-especially in Slovenia but also in other countries-express confidence in existing sustainable forest management strategies and regulations, which they expect to secure all forest ES.

The results furthermore indicate that stakeholders perceive employment as the main synergy regarding energy wood production. This synergy is a side-objective of renewable energy policies and-especially in rural areas-remains an important aim of enforced energy wood production and use [10, 23, 50, 56]. Different studies support the assumption that energy wood production and use can have a positive influence on the development of rural economies and employment [57-60]. The importance of tapping the potential of this synergy is emphasised in Spain where the recent economic crisis had the most severe impacts on labour markets compared to the other countries [61], and where energy wood production could thus be promoted for its positive effect on employment and moreover for its potential synergies with fire prevention.

Amongst the trade-offs between energy wood production and use and other forest ES that are perceived by stakeholders, biodiversity is the most critical and dominant one discussed. Biodiversity conservation has been prominent in political and societal discourses over recent decades, but was-related to forests-mainly restricted to the context of timber production $[4,10,62-64]$. Verkerk et al. [63] and Ferranti [65] describe the interrelationship between timber production and forest protection as a classical dilemma, and this holds true for the interrelationship between energy wood production and forest protection, and-more generally speaking-for any kind of forest production. In line with this, Söderberg and Eckerberg [10] classify biodiversity protection as one of the four main potential conflict issues related to different bioenergy policies at EU level, even though some synergies might also be realised. On the basis of our interviews, we agree that an increasing energy wood demand may increase existing conflicts between nature conservation and forest production.

Recent studies support our findings that some stakeholders from Finland, Germany, and especially Slovenia perceive negative effects of restrictions for biodiversity conservation on the production of energy wood. Edwards and Kleinschmit [4] identify that many stakeholders and public actors reject forest protection in its basic form. Current debates, e.g. about the designation of additional national parks in Germany, might influence stakeholders' perceptions about conservation measures. Nevertheless, possible trade-offs as discussed by stakeholders exist: for instance, Verkerk et al. [63] anticipate that existing protection of forests might influence the supply of wood if the demand for material or energy uses increases significantly.

The main concerns regarding biodiversity relate to the use of harvesting residues for energy wood and to the conservation of dead wood. While many stakeholders highlight that energy wood is and will be a by-product of regular forest management, others doubt that existing regulations prevent over-use and emphasise the importance of harvesting residues and dead wood for soil nutrients' balance and biodiversity. Synergies between energy wood production and biodiversity are emphasised in Spain, where different ecological conditions prevail compared to the other countries: Mediterranean forests are characterised by openness; therefore, many species benefit from wood harvesting [66-69]. However, an increasing energy wood production in Spain needs to take into account recommendations for prioritising and spatiotemporal management of forests in order to achieve overall benefits for biodiversity [66-69].

Whereas stakeholders in all countries focus on different provisioning, regulating and supporting ES, they hardly address cultural ES, although interviewers explicitly asked for trade-offs and synergies between energy wood production and recreation. The interview results indicate that stakeholders do not consider cultural ES to be a main issue. Our interpretation of this result is that they think that lay people quickly adapt to different forms of forest production. However, lay people have varying preferences relating to forest types and structures for 
recreational and leisure activities, with country-specific and regional differences [38, 70-77]. Effects of (energy) wood production on recreational values are therefore likely $[10$, $71,72,76]$. Based on our results, we thus support Cambero and Sowlati [32], who identify research needs regarding cultural impacts of energy wood production. From our perspective, these impacts will likely influence society's acceptance of energy wood production and use.

Looking ahead, only few stakeholders, mainly from conservation and policy groups, expect effects of energy wood production and use on other forest ES. This might extend from their perception of energy wood as a byproduct of roundwood production, which many stakeholders favour in any case and are thus opposed to silvicultural or management changes towards energy wood production. Blennow et al. [26] support the expectation that forest management and silviculture will not change towards a stronger focus on energy wood production. Other studies imply that private forest owners make management decisions based on other values and sociodemographic background, as well as economic factors. They are willing to increase energy wood supply but mainly because of improved conditions for roundwood extraction and general commercial opportunities [24, 26-31].

\section{Conclusions}

In this qualitative empirical study, we analysed 103 stakeholder interviews from Finland, Germany, Norway, Slovenia and Spain about trade-offs and synergies between (increasing) energy wood production and use and other forest ES. We based our work on the premise that effects of energy wood production and use need to be taken into account in order to cope with current and future trade-offs and to tap the full potential of synergies related to other forest ES. Therefore, our objective was to provide a qualitative overview of perceptions of stakeholders on current and future effects of energy wood production and use.

The results of this study highlight the importance of taking into account the effects of energy wood production and use in policy development and forest management in order to address current and future trade-offs and to tap the full potential of synergies related to other forest ES. As the diversity amongst the studied countries shows, different characteristics of countries and regions need to be considered, and tailored solutions for a balanced energy wood production and use need to be found. In order to achieve such a balance, it is crucial that stakeholder groups focus their discussion on feasible solutions, which need to be fostered by long-term and far-reaching political frameworks. As an example, the trade-off between energy wood use and air quality should not just point to questions of efficiency but also to questions of sufficiency, which are currently not present on the political agenda.

\section{Competing interests}

The authors declare that they have no competing interests.

\section{Authors' contributions}

$\mathrm{DMP}, \mathrm{KW}, \mathrm{BB}, \mathrm{TP}$ and RR developed the concept and the design of the study. DMP, KW and BB collected and analysed the data from Germany; EGM collected and analysed the data from Spain; LK and MK collected and analysed the data from Finland; JK, VL, ŠPM and LZS collected and analysed the data from Slovenia; and BHL and BS collected and analysed the data from Norway. DMP and KW drafted the manuscript. FF, EGM, LK, JK, MK, VL, $\mathrm{BHL}$, ŠPM, TP, BS and LZS critically revised it several times. All authors read and approved the final manuscript.

\section{Acknowledgements}

The study was conducted within the COOL project (COmpeting uses Of forest Land), a project within the two ERA-Nets WoodWisdom-Net 2 and Bioenergy, and with financial support from the Federal Ministry of Education and Research (programme manager: Project Management Jülich) in Germany, the Ministry of Agriculture and Forestry in Finland, the Research Council of Norway, the Ministry of Education, Science and Sport in Slovenia, and the Ministry of Economy and Competitiveness in Spain. The article processing charge was funded by the German Research Foundation (DFG) and the Albert Ludwigs University Freiburg in the funding programme Open Access Publishing. The authors also thank the interviewees, Carolin Maier and two anonymous peers for thoughtful inputs, and Emily Kilham for professional proofreading.

\section{Author details}

${ }^{1}$ Chair of Forest and Environmental Policy, University of Freiburg, Tennenbacher Str. 4, Freiburg 79106, Germany. ${ }^{2}$ Department Forest and Society, Forest Research Institute Baden-Württemberg, Wonnhaldestrasse 4, Freiburg 79100, Germany. ${ }^{3}$ Nationalpark Schwarzwald, Schwarzwaldhochstrasse 2, Seebach 77889, Germany. ${ }^{4}$ Nature\&Society Consultancy in Research and Publishing, Dreikoenigstrasse 47-30b, 79102 Freiburg, Germany. ${ }^{5}$ Forest Economics department, Forest Sciences Center of Catalonia (CTFC) and European Forest Institute - Mediterranean Regional Office (EFIMED), St. Pau Art Nouveau Site - St.Leopold pavilion. St. Antoni Maria Claret 167, Barcelona 08025, Spain. ${ }^{6}$ Natural Resource Institute Finland, PO Box 68, Joensuu FI-80101, Finland. ${ }^{7}$ Department of Forestry and Renewable Forest Resources, Biotechnical Faculty, University of Ljubljana, Večna pot 83, Ljubljana 1000, Slovenia. ${ }^{8}$ Department of Ecology and Natural Resource Management, Norwegian University of Life Sciences, P.O Box 5003, Aas NO-1432, Norway. ${ }^{9}$ UNIQUE forestry and land use $\mathrm{GmbH}$,

Schnewlinstraße 10, Freiburg 79098, Germany.

Received: 13 February 2015 Accepted: 7 May 2015

Published online: 21 May 2015

\section{References}

1. EEA (2012) Climate change, impacts and vulnerability in Europe 2012. An indicator-based report, EEA (European Environment Agency)

2. MA (2005) Millennium Ecosystem Assessment - Ecosystems and Human Well-being: Biodiversity Synthesis

3. van Oudenhoven APE, Petz K, Alkemade R, Hein L, De Groot R (2012) Framework for systematic indicator selection to assess effects of land management on ecosystem services. Ecol Indicat 21:110-122. doi:10.1016/ j.ecolind.2012.01.012

4. Edwards P, Kleinschmit D (2013) Towards a European forest policy—conflicting courses. Forest Policy Econ 33:87-93. doi:10.1016/j.forpol.2012.06.002

5. AEBIOM Europe (2013) A bioenergy outlook 2013: statistical report

6. COM (2013) Report from the Commission to the European Parliament, the Council, the European Economic and Social Committee and the Committee of the Regions: renewable energy progress report. Brussels

7. Stupak I, Asikainen A, Jonsell M, Karltun E, Lunnan A, Mizaraitè D, Pasanen K, Pärn $H$, Raulund-Rasmussen K, Röser D, Schroeder M, Varnagintè I, Vilkriste L, Callesen I, Clarke N, Gaitnieks T, Ingerslev M, Mandre M, Ozolincius R, Saarlami A, Armolaitis K, Helmisaari H-S, Indriksons A, Kairiukstis L, Katzensteiner K, Kukkola M, Ots K, Ravn HP, Tamminen P (2007) Sustainable utilization of forest biomass for energypossibilities and problems: policy, legislation, certification, and recommendations 
and guidelines in the Nordic, Baltic, and other European countries. Biomass Bioenergy 31(10):666-684. doi:10.1016/j.biombioe.2007.06.012

8. Muys B, Hetemäki L, Palahi M (2013) Sustainable wood mobilization for EU renewable energy targets. Biofuels Bioprod Bioref 7:359-360. doi:10.1002/ bbb.1421

9. Verkerk PJ, Anttila P, Eggers J, Lindner M, Asikainen A (2011) The realisable potential supply of woody biomass from forests in the European Union. For Ecol Manage 261(11):2007-2015

10. Söderberg C, Eckerberg K (2013) Rising policy conflicts in Europe over bioenergy and forestry. Forest Policy Econ 33:112-119, doi:http://dx.doi.org/ 10.1016/j.forpol.2012.09.015

11. Gamborg C, Anker HT, Sandøe P (2014) Ethical challenges in bioenergy governance: coping with value disagreements and regulatory complexity. Energy Policy 69:326-333. doi:10.1016/j.enpol.2014.02.013

12. Haase D, Schwarz N, Strohbach M, Kroll F, Seppelt R (2012) Synergies, trade-offs, and losses of ecosystem services in urban regions: an integrated multiscale framework applied to the Leipzig-Halle Region, Germany. Ecol Soc 17(3):1-22. doi:10.5751/ES-04853-170322

13. Juutilainen K, Mönkkönen M, Kotiranta H, Halme P (2014) The effects of forest management on wood-inhabiting fungi occupying dead wood of different diameter fractions. For Ecol Manage 313:283-291. doi:10.1016/ j.foreco.2013.11.019

14. Janowiak MK, Webster CR (2010) Promoting ecological sustainability in woody biomass harvesting. J Forestry 801(1):16-23

15. Riffell S, Verschuyl J, Miller D, Wigley TB (2011) Biofuel harvests, coarse woody debris, and biodiversity - a meta-analysis. For Ecol Manage 261(4):878-887. doi:10.1016/j.foreco.2010.12.021

16. Verkerk PJ, Lindner M, Zanchi G, Zudin S (2011) Assessing impacts of intensified biomass removal on deadwood in European forests. Ecol Indicators 11:27-35. doi:10.1016/j.ecolind.2009.04.004

17. Meller L, van Vuuren DP, Cabeza M (2013) Quantifying biodiversity impacts of climate change and bioenergy: the role of integrated global scenarios. Reg Environ Change 13(4):1-11. doi:10.1007/s10113-013-0504-9

18. Ponnikas J (2012) Social impact assessment of forest energy production. In: Marcianò C, Menguzzato G (eds) Bioenergy and sustainable forestry: good practices in Italy and Finland. Università degli Studi Mediterranea di Reggio Calabria, Reggio Calabria, pp 30-39

19. Raunikar R, Buongiorno J, Turner JA, Zhu S (2010) Global outlook for wood and forests with bioenergy demand implied by scenarios of the intergovernmental panel on climate change. Forest Policy Econ 12:48-56. doi:10.1016/j.forpol.2009.09.013

20. Schraml U, von Detten R (2010) Forestry or "the art of flying blind"- sustainability in an era of global change. In: Spathelf P (ed) Sustainable forest management in a changing world: a European perspective. Springer, Luxemburg, Berlin, pp 217-235

21. Lamers $P$, Thiffault $E$, Paré $D$, Junginger M (2013) Feedstock specific environmental risk levels related to biomass extraction for energy from boreal and temperate forests. Biomass Bioenergy 55:212-226. doi:10.1016/ j.biombioe.2013.02.002

22. Härtl F, Knoke T (2014) The influence of the oil price on timber supply. Forest Policy Econ 39:32-42. doi:10.1016/j.forpol.2013.11.001

23. Stupak I, Lattimore B, Titus BD, Smith CT (2011) Criteria and indicators for sustainable forest fuel production and harvesting: a review of current standards for sustainable forest management. Biomass Bioenergy 35:23873308. doi:10.1016/j.biombioe.2010.11.032

24. Brough P, Rørstad PK, Breland TA, Trømborg E (2013) Exploring Norwegian forest owners' intentions to provide harvest residues for bioenergy. Biomass Bioenergy 57:57-67. doi:10.1016/j.biombioe.2013.04.009

25. Schmithüsen F, Hirsch F (2010) Private forest ownership in Europe. In: Geneva timber and forest study paper 26. UNECE. http://www.unece.org/ fileadmin/DAM/timber/publications/SP-26.pdf Accessed 14.05.2015

26. Blennow K, Persson E, Lindner M, Pacheco Faias S, Hanewinkel M (2014) Forest owner motivations and attitudes towards supplying biomass for energy in Europe. Biomass Bioenergy 67:223-230. doi:10.1016/j.biombioe.2014.05.002

27. Rämö A-K, Järvinen E, Latvala T, Toivonen R, Silvennoinen H (2009) Interest in energy wood and energy crop production among Finnish non-industrial private forest owners. Biomass Bioenergy 33:1251-1257. doi:10.1016/ j.biombioe.2009.05.013

28. Bohlin F, Roos A (2002) Wood fuel supply as a function of forest owner preferences and management styles. Biomass Bioenergy 22:237-249. doi:10.1016/S0961-9534(02)00002-8
29. Mynttinen S, Karttunen K, Ranta T (2014) Non-industrial private forest owners' willingness to supply forest-based energy wood in the South Savo region in Finland. Scand J Forest Res 29(1):41-50. doi:10.1080/ 02827581.2013 .856935

30. Gruchy SR, Grebner DL, Munn IA, Joshi O, Hussain A (2012) An assessment of nonindustrial private forest landowner willingness to harvest woody biomass in support of bioenergy production in Mississippi: a contingent rating approach. Forst Policy Econ 15:140-145. doi:10.1016/j.forpol.2011.09.007

31. Halder P, Paladinić E, Stevanov M, Orlović S, Hokkanen TJ, Pelkonen P (2014) Energy wood production from private forests-nonindustrial private forest owners' perceptions and attitudes in Croatia and Serbia. Renew Sustain Energy Rev 35:515-526. doi:10.1016/j.rser.2014.04.038

32. Cambero C, Sowlati T (2014) Assessment and optimization of forest biomass supply chains from economic, social and environmental perspectives-a review of literature. Renew Sustain Energy Rev 36:62-73. doi:10.1016/ j.rser.2014.04.041

33. Huttunen S (2014) Stakeholder frames in the making of forest bioenergy legislation in Finland. Geologija 53:63-73. doi:10.1016/ j.geoforum.2014.02.006

34. Witzel A (2000) The problem-centered interview. Forum: Qualitative Social Research 1 (1):Art. 22. doi:http://nbn-resolving.de/urn:nbn:de:0114-fas0001228

35. Kruse J, Biesel K, Schmieder C (2011) Metaphernanalyse-ein rekonstruktiver Ansatz (analysis of metaphors - a reconstructive approach). Springer, New York

36. Bohnsack R (2008) Rekonstruktive Sozialforschung: Einführung in qualitative Methoden (reconstructive social research: introduction to qualitative methods), 7th edn. UTB GmbH, Opladen

37. Bauer J, Kniivilä M, Schmithüsen F (2004) Forest legislation in Europe: how 23 countries approach the obligation to reforest, public access and use od non-wood forest products. Geneva timber and forest discussion Paper 37. UNECE. http://www.fao.org/3/a-ae892e.pdf Accessed 14.05.2015

38. Bell S, Simpson M, Tyrväinen L, Sievänen T, Pröbstl U (2009) European forest recreation and tourism: a handbook. Taylor \& Francis, London and New York

39. Mayring P (2010) Qualitative Inhaltsanalyse: Grundlagen und Techniken (qualitative content analysis: principles and techniques), 11th edn. Beltz, Weinheim

40. Gläser J, Laudel G (2013) Life with and without coding: two methods for early-stage data analysis in qualitative research aiming at causal explanations. Forum: Qualitative Social Research 14(2):Art. 5

41. De Groot RS, Wilson MA, Boumans RMJ (2002) A typology for the classification, description and valuation of ecosystem functions, goods and services. Ecol Econ 41:393-408. doi:10.1016/S0921-8009(02)00089-7

42. Layke C, Mapendembe A, Brown C, Walpole M, Winn J (2012) Indicators from the global and sub-global Millennium Ecosystem Assessments: an analysis and next steps. Ecol Indicators 17:77-87. doi:10.1016/ j.ecolind.2011.04.025

43. TEEB (2014) The economics of ecosystems and biodiversity http:// www.teebweb.org/resources/ecosystem-services/ Accessed 19.11.14

44. San Miguel J, Camia A (2009) Forest fires at a glance: facts, figures and trends in the EU. In: Birot F (ed) Living with wildfires: what science can tell us, vol 15, EFI Discussion paper., pp 15-18

45. Kärkkäinen L, Kurttila M, Salminen O, Viiri H (2014) Effects of energy wood harvesting on timber production potential and biological diversity in North Karelia, Finland. Forst Sci 60(6):1077-1088, doi:http://dx.doi.org/10.5849/ forsci.13-041

46. Mann C, Pouta E, Gentin S, Jensen FS (2010) Outdoor recreation in forest policy and legislation: a European comparison. Urban Forestry Urban Greening 9:303-312. doi:10.1016/j.ufug.2010.06.004

47. MCPFE (2005) National Forest Programmes in Europe. Warshaw

48. Pröbstl U, Wirth V, Elands B, Bell S (2010) Management of recreation and nature based tourism in European forests. Springer-Verlag, Berlin Heidelberg. doi:10.1007/978-3-643-03145-8

49. Ministry of Employment and the Economy Finland (2010) Finland's national action plan for promoting energy from renewable sources pursuant to Directive 2009/28/EC. Employment and the Economy Energy Department, Ministry of

50. COM (2009) Directive 2009/28/EC of the European Parliament and of the Council of 23 April 2009 on the promotion of the use of energy from renewable sources and amending and subsequently repealing Directive 2001/77/EC and 2003/30/EC. COM (Commission of the European Communities)

51. Hickey GM, Innes $J$ (2005) Monitoring sustainable forest management in different jurisdictions. Environ Monit Assess 108:241-260. doi:10.1007/ s10661-005-4329-y 
52. Buijs A, Lawrence A (2013) Emotional conflicts in rational forestry: towards a research agenda for understanding emotions in environmental conflicts. Forest Policy Econ 33:104-111. doi:10.1016/j.forpol.2012.09.002

53. Dickie IA, Bennett BM, Burrows LE, Nunez MA, Peltzer DA, Porté A, Richardson DM, Rejmánek M, Rundel PW, van Wilgen BW (2014) Conflicting values: ecosystem services and invasive tree management. Biol Invasions 16:705-719. doi:10.1007/s10530-013-0609-6

54. Lindahl KB, Westholm E (2012) Future forests: perceptions and strategies of key actors. Scand J Forest Res 27(2):154-163. doi:10.1080/02827581.2011.635073

55. Winkel G (2006) Waldnaturschutzpolitik in Deutschland - Bestandsaufnahme, Analysen und Entwurf einer Story-Line. Inaugral-Dissertation, AlbertLudwigs-Universität Freiburg (Forest conservation policies in Germanyinventory, analyses and conception of a story-line. Inaugural-dissertation, University of Freiburg)

56. Wolfsmayr UJ, Rauch P (2014) The primary forest fuel supply chain: a literature review. Biomass Bioenergy 60:203-221. doi:10.1016/ j.biombioe.2013.10.025

57. Domac J, Richards K, Risovic S (2005) Socio-economic drivers in implementing bioenergy projects. Biomass Bioenergy 28:97-106. doi:10.1016/j.biombioe. 2004.08.002

58. Forbord M, Vik J, Hillring BG (2012) Development of local and regional forest based bioenergy in Norway-supply networks, financial support and political commitment. Biomass Bioenergy 47:164-176. doi:10.1016/ j.biombioe.2012.09.045

59. Kallio AMI, Salminen O, Sievänen R (2013) Sequester or substituteconsequences of increased production of wood based energy on the carbon balance in Finland. J Forest Econ 19:402-415. doi:10.1016/j.jfe.2013.05.001

60. Krajnc N, Domac J (2007) How to model different socio-economic and environmental aspects of biomass utilisation: case study in selected regions in Slovenia and Croatia. Energy Policy 35:6010-6020. doi:10.1016/ j.enpol.2007.08.006

61. Tridico P (2013) The impact of the economic crisis on EU labour markets: a comparative perspective. Int Labour Rev 152(2):175-190. doi:10.1111/j.1564913X.2013.00176.X

62. Niemelä J, Young J, Alard D, Askasibar M, Henle K, Johnson R, Kurttila M, Larsson T-B, Matouch S, Nowicki P, Paiva R, Portoghesi L, Smulders R, Stevenson A, Tartes U, Watt A (2005) Identifying, managing and monitoring conflicts between forest biodiversity conservation and other human interests in Europe. Forest Policy Econ 7:877-890. doi:10.1016/j.forpol.2004.04.005

63. Verkerk PJ, Zanchi G, Linder M (2014) Trade-offs between forest protection and wood supply in Europe. Environ Manage 53:1085-5294. doi:10.1007/ s00267-014-0265-3

64. Winkel G, Gleißner J, Sotirov GM, Storch S (2011) The sustainably managed forests heats up: discursive struggles over forest management and climate change in Germany. Crit Policy Stud 5(4):361-390. doi:10.1080/ 19460171.2011.628002

65. Ferranti $F$ (2014) Energy wood: a challenge for European forests. Potentials, environmental implications, policy integration and related conflicts. Eur Forest Inst Tech Rep. http://www.efi.int/files/attachments/publications/ efi_tr_95_ferranti_2014.pdf Accessed 30.03.2015

66. Porto M, Correia O, Beja P (2011) Long-term consequences of mechanical fuel management for the conservation of Mediterranean forest herb communities. Biodivers Conserv 20:2669-2691. doi:10.1007/s10531-011-0098-9

67. Ruiz-Benito P, Gómez-Aparicio L, Zavala MA (2012) Large-scale assessment of regeneration and diversity in Mediterranean planted pine forests along ecological gradients. Divers Distrib 18(11):1092-1106. doi:10.1111/j.14724642.2012.00901.x

68. Santana J, Porto M, Gordinho L, Reino L, Beja P (2012) Long-term responses of Mediterranean birds to forest fuel management. J Appl Ecol 49:632-643. doi:10.1111/j.1365-2664.2012.02141.x

69. Verdasca MJ, Leitão AS, Santana J, Porto M, Dias S, Beja P (2012) Forest fuel management as a conservation tool for early successional species under agricultural abandonment: the case of Mediterranean butterflies. Biol Conserv 146:14-23. doi:10.1016/j.biocon.2011.10.031

70. Blasco E, González-Olabarriara JR, Rofriguéz-Veiga P, Pukkala T, Kolehmeinen O, Palahí M (2009) Predicting scenic beauty of forest stands in Catalonia (North-east Spain). J Forest Res 20(1):73-78. doi:10.1007/s11676-009-0013-3

71. Edwards D, Jay M, Jensen FS, Lucas B, Marzano M, Montagné C, Peace A, Weiss G (2012) Public preferences for structural attributes of forests: towards a pan-European perspective. Forst Policy Econ 19:12-19. doi:10.1016/ j.forpol.2011.07.006
72. Edwards DM, Jay M, Jensen FS, Lucas B, Marzano M, Montagné C, Peace A, Weiss G (2012) Public preferences across Europe for different forest stand types as sites for recreation. Ecol Soc 17(1):27. doi:10.1016/ j.forpol.2011.07.006

73. Golos P (2013) Selected aspects of the forest recreational function in view of its users. Leśne Prace Badawcze (Forest Research Papers) 74(3):257-272. doi:10.2478/frp-2013-0025

74. Gundersen S, Frivold LH (2008) Public preferences for forest structures: a review of quantitative surveys from Finland, Norway and Sweden. Urban Forestry Urban Greening 7:241-258. doi:10.1016/j.ufug.2008.05.001

75. Kanowski PJ, Williams KJH (2009) The reality of imagination: integrating the material and cultural values of old forests. Forest Ecol Manage 258:341-346. doi:10.1016/j.foreco.2009.01.011

76. Zandersen M, Tolc RSJ (2009) A meta-analysis of forest recreation values in Europe. J Forest Econ 15:109-130. doi:10.1016/j.je.2008.03.006

77. Zheng B, Zhang Y, Chen J (2011) Preference to home landscape: wildness or neatness? Landscape Urban Plan 99:1-8. doi:10.1016/ j.landurbplan.2010.08.006

78. EEA (2011) Directive on the promotion of renewable energy incorporated. European Economic Area. http://www.efta.int/eea/eea-news/2011-12-20-jcrenewable-energy.aspx Accessed 16.03.15

79. UNECE/FAO (2013) UNECE/FAO joint wood energy enquiry (JWEE) 2013. United Nations, Geneva

80. Haberl H, Geissler S (2000) Cascade utilization of biomass: strategies for a more efficient use of a scarce resource. Ecol Eng 16:111-121. doi:10.1016/ S0925-8574(00)00059-8

\section{Submit your manuscript to a SpringerOpen ${ }^{\circ}$ journal and benefit from:}

- Convenient online submission

- Rigorous peer review

- Immediate publication on acceptance

- Open access: articles freely available online

- High visibility within the field

- Retaining the copyright to your article

Submit your next manuscript at springeropen.com 